\title{
NUP98/KDM5A Fusion Protein
}

National Cancer Institute

\section{Source}

National Cancer Institute. NUP98/KDM5A Fusion Protein. NCI Thesaurus. Code C105816.

A fusion protein encoded by the NUP98/KDM5A fusion gene. This protein is comprised of the $\mathrm{N}$-terminal nucleoporin GLFG repeat domains of the nuclear pore complex protein Nup98-Nup96 protein fused to the C-terminal PHD domain of the lysine-specific demethylase $5 \mathrm{~A}$ protein. 